\title{
Use of Mobile Dictionary in University Students' Class: A Study of Teachers' Perspective in Pakistan
}

\author{
Muhammad Din (Corresponding author) \\ Department of English, The Islamia University of Bahawalpur, Pakistan. \\ E-mail:mduaau@gmail.com
}

Received: October 9, 2019 Accepted: November 14, 2019 Published: November 16, 2019

doi:10.5296/elr.v5i2.15839 URL: https://doi.org/10.5296/elr.v5i2.15839

\begin{abstract}
Revolutionary changes have been brought about in teaching and learning environment with the introduction of electronic formats in classrooms. Mobile dictionaries are potentially valuable learning tools today. This study has strived to get insight into the prospects of using mobile dictionary in an EFL classroom of university students of Pakistan with reference to teachers' perspective. The aims of this study are to know foreign language teachers' point of view regarding the use of mobile dictionary in English class, investigate the challenges in introducing this e-tool and explore the benefits EFL learners can have through the use of mobile dictionaries in English class. To achieve the objectives of this quantitative study, the researcher has got a questionnaire filled by fifty English language teachers working at different government colleges in Pakistan. The questionnaire which was used to collect data from college teachers consisted of two sections. The first section comprised of fifteen questionnaire items on five-point Likert scale the second section consisted of two open-ended questions. The reliability of the first part of the questionnaire was computed through SPSS (XX). It has been found that most of the college teachers are of the view that the use of mobile dictionary in an EFL class of university students will help them learn vocabulary, pronunciation of words and word origin. These EFL learners can also access authentic content and develop their language competence through the use of mobile phone dictionary in the class. Apart from this, the participants have also pointed out some problems which can be a hindrance in using mobile dictionary in an EFL classroom in the context of Pakistan.
\end{abstract}

Keywords: Mobile dictionary, EFL learners, Vocabulary, Prospects

\section{Introduction}

The learning and teaching environment have been revolutionized remarkably by the unprecedented advancement brought about by communication and information technologies. The rapid evolution and use of mobile devices have opened up new horizons of academic 


\section{Al Macrothink}

world and learning experiences. So have new opportunities been created for the integration of modern technology into instruction. For instance, mobile phones have become efficient learning tools because of their ubiquity among the students at schools and universities.

\subsection{What is Dictionary}

The dictionary, the prototypical work of lexical reference, classifies and stores information on words, phrases, and other lexical items, including their form, meaning, use, origin, and history (Kirkness, 2004). It is one of the oldest and the most widespread books in literate societies, and the number of its titles is enormous (Kirkness, 2004). There may be two types of dictionary i.e. printed dictionary and digital dictionary. In order to grasp of words and to have better understanding of them, we use different type of dictionaries.

\subsection{Types of Dictionary}

There are different types of dictionary such as bilingual, monolingual, specialized, etymological, rhyming, pocket dictionary, dictionary of literary terms, thesaurus and glossary.

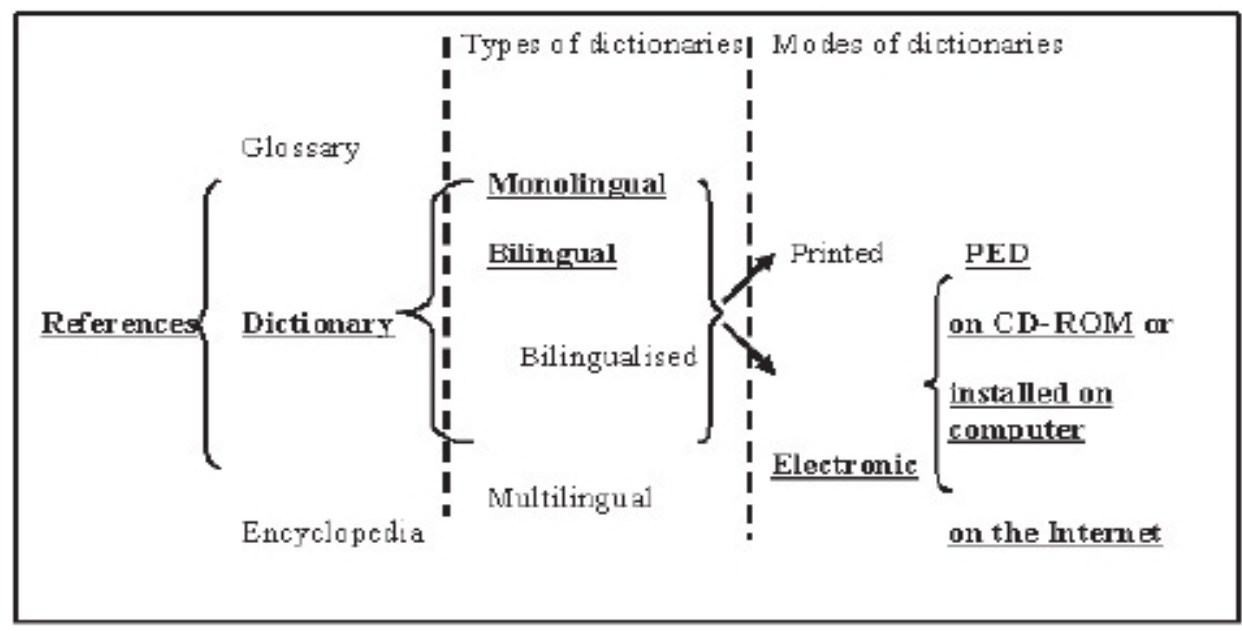

Figure 1. Students' use and knowledge of electronic dictionaries

Retrieved from ABAC Journal

\subsection{Dictionary as a Store House of Lexical Items}

It has been said that the better vocabulary ensures students' success in their academic career. Using a dictionary in EFL classroom is very important because it not only helps the students in understanding the difficult material but also saves them from misinterpreting it. Through the use of mobile phone dictionaries, EFL learners can build their vocabulary, make their spellings correct and produce writing easy to understand. Dictionary is the store house of lexical items and enjoying the mastery of this store house makes the learners fluent and proficient in speaking the language. It has become crucial to investigate how such materials are used and what impact they have on L2 learning. Pocket electronic dictionaries (PEDs) have particularly become popular among Asian learners of English. Electronic dictionaries typically store much more than the entire content of thick paper dictionaries and offer direct access to corpus examples and citation banks and open a number of new search routes, such as tracking down a target word via phonologically similar or lexically related words (Nesi, 
1999). E-dictionaries may be online, CD-Room based and mobile dictionaries.

\subsection{Electronic Dictionary}

Electronic dictionaries are very different from paper dictionaries with respect to their outer and inner access structures, i.e. indicators which help dictionary users locate specific entries on the one hand, and those which guide them inside the entries to find the required information (Bergenholtz \& Gouws, 2007). Koga (1995) compared the effectiveness of an online E. Dictionary and a P. Dictionary for L2 reading. He concludes that the E. Dictionary had less interference in the reading process and facilitates students' comprehension. Inami et al. (1997) have compared a CD-ROM based Dictionary and P. Dictionary. They took two types of vocabulary tests, the tests that required supplying either the definitions or spellings of the learned words. They are of the view that students rated the CD-ROM dictionary as more efficient for learning than the P. Dictionary.

\subsection{Use of Mobile Phone Dictionary}

Mobile phones can be used as learning tools in a classroom because of the advantages they can render to this end. These affordances include portability, context sensitivity, social interactivity, individuality and connectivity (Klopfer \& Squire, 2008 as cited in Rahimi \& Miri, 2014, p. 1470). Kukulska-Hulme and Shield (2008) also maintain that Mobile Assisted Language Learning (MALL) emphasizes spontaneity or continuity of access and ensures in different contexts. Rahimi and Miri (2014) claim that mobile phone dictionaries can help EFL learners develop their vocabulary particularly their knowledge of synonyms, antonyms, idioms, collocations and phrases. Joseph and Uther (2009) as cited in Rahimi and Miri, 2014, p. 1474) argue that mobile phone dictionaries also help language learners to improve their pronunciation and refine their concepts regarding the meaning of words by watching videos and images related to words.

In the present-day world, new technologies are bringing the students particularly university students different forms of electronic literacies which play an important role in connecting them with their peers in a "networked society" (Castells, 2000; Lankshear \& Knobel, 2003; Warschaur, 1999). Electronic dictionaries are very important and useful tool for EFL learners among these technologies. Mobile phone dictionary is the most recent app which is available on smart phones and tablets. Mobile phone dictionaries are marked with the functions of interactive learning which include speech features, vocabulary games and reference book (Zheng \& Wang, 2016).

\subsection{Significance of English}

English has become an international language or an international lingua franca. It has achieved such a status as is recognized by every country across the world. In Pakistan, English occupies a place of honor and prestige among the languages spoken here. In recent times, owing to the remarkable success of the English-speaking nations in the fields of industry and politics, the people, governments, and institutions have steered their focus and interest towards this language. It has generally been observed that strong language competence renders students good pedestal and they get entry into higher institutions as the learning of English language wields so much intense importance in Pakistan in the present scenario. English has also become the symbol of education and an elite status in the Pakistani 
society and has become the language of media, science, technology and a means of inter-national as well as intra-national communication. Ghani (2003) styles this language "a gateway to success" in Pakistan. Akram and Mehmood (2007) have analyzed the factors which motivate the Pakistani students to go for the learning of English language. They claim that the motivational factors like studies abroad, greater job opportunities, social or missionary aspirations, better economic prospects and academic ends make them learn this language.

\subsection{Objectives of the Study}

The objectives of this study have been given as follows;

$>$ To know EFL teachers' perception regarding the use of mobile phone dictionaries in university students' English class.

$>$ To explore the challenges in the introduction of mobile phone dictionaries in university students' English class.

\subsection{Research Questions}

The research questions of the present study have given as follows;

$>$ What is the EFL teachers' perception regarding the use of mobile phone dictionaries in university students' English class?

What are the challenges in the introduction of mobile phone dictionaries in university students' English class?

\section{Literature Review}

Ayoub et al. (2017) have conducted a study in Pakistani context to explore the Secondary School EFL learners' dictionary using habits. This study has also highlighted the hindrances which pose problems for these learners and teachers in using dictionaries properly. The researchers have used questionnaire and conducted structured interviews to collect data from the subjects of their study. The results of this study show that bilingual dictionaries are not used by $75.6 \%$ of the participants and monolingual dictionaries are not used by $80 \%$ of them. According to the results of this study, students mostly consult dictionaries because of the assigned textbooks and delivered lectures. Whereas, $79.2 \%$ of the participants claim that they resort to dictionaries just to look up the meanings of words. So far as the habits of these EFL learners regarding the use of dictionaries are concerned, $84 \%$ of the participants maintain that they do not use dictionary in classroom.

Mohammad et al. (2017) have carried out a qualitative study to find out the advantages of e-dictionaries for the Malaysian EFL learners highlight the difficulties faced by them in the use of these dictionaries. The participants of this study consisted of ten undergraduate students who were from Teaching English as Second Language (TESL) course. An open-ended questionnaire, email responses and focus group interviews were used as research instruments of this study. The findings of this study reveal that both EFL teachers and students have positive perception regarding the use of e-dictionaries in language learning. On the other hand, this study has also highlighted the difficulties faced by EFL teachers and students in using e-dictionaries. Limited internet access, incomplete definition of words, and classroom distraction are the factors which have been brought to light in this study. According to this study, these factors hamper EFL learners in their independent learning. 
Deshtestani (2013) has conducted a study to compare EFL teachers' and learners' perspective regarding the use of e-dictionaries English. The participants of this study consisted of $66 \mathrm{EFL}$ teachers and 81 EFL learners. The researcher has used a questionnaire to explore the prospective of the participants of this study. According to the results of the study, both the teachers and students showed positive perception regarding the use of e-dictionaries in the process of language learning. This study shows that audio-visual features, time efficiency, portability, input for enhancing students' autonomy and ease of access and use are the features because of which EFL learners and teachers think that e-dictionaries should be used in learning English as a foreign language. However, this study also highlights some issues which can pose problems in the use of e-dictionaries in an EFL classroom. For instance, this study argues that lack of training, poor quality of audio and distraction are the problems which pose challenges in the use of e-dictionaries.

Rahimi and Miri (2014) have conducted a pretest-posttest quasi-experimental study to investigate the impact of the use of mobile phone dictionary on language learning. This study has found out that the use of mobile phone dictionary has caused higher level of language learning than printed dictionaries. The researchers also claim that the mean score of experimental group (85.29) is higher than that of the control group (77.35). Stingling (2005) claims that students from eastern Asian countries exclusively prefer electronic dictionaries because of the educational systems which lay stress more on accuracy than risk-taking and guessing in language learning and teaching. Likewise, Midlane (2005) has also found out that students from eastern Asian countries showed eagerness to use electronic dictionaries in an EFL class. Korat and Shamir (2006) believe that electronic dictionaries render positive pay offs regarding EFL learning. According to them, "read-with-dictionary tasks" are more useful than "read-only tasks".

Zheng and Wang (2016) have conducted a study to investigate the issues related to the pros and cons of integrating electronic dictionaries into EFL teaching. In this study, the researchers have shared teachers' point of view relating the introduction of electronic dictionaries in an EFL classroom. This study reveals that challenging reading material can be presented to EFL learners through electronic dictionaries. Zheng and Wang (ibid) have also highlighted the issue that such dictionaries are distracting and noisy. According to the researchers, some teachers maintain that paper dictionaries are better than electronic dictionaries because they (paper dictionaries) are compiled by those who are language experts and they design paper dictionaries purely for language learners. Whereas, electronic dictionaries are produced by technological companies.

Alhaisoni (2016) has conducted a study to explore students' and teachers' perception regarding their preference and choice to a particular dictionary/dictionaries and their dictionary practices "in the Preparatory Year at the University of Ha'il, Saudi Arabia". The participants of this study consisted of 3993 male and female EFL learners who were enrolled in "English Language Program at the University of Ha'il". This study has used student as well as teacher questionnaire for data collection. The researcher has also conducted semi-structured interviews to get an insight into students' preferences and use of dictionaries. The results of this study show that students use all types of dictionaries because they have been found relatively less sophisticated dictionary users. But Alhaisoni (ibid) has also found 


\section{MInstitute ${ }_{\text {Mnk }}^{\text {Macrothink }}$}

that EFL learners use E-A bilingual dictionary more than other types of dictionaries ( $p$ $=.001)$. This study has also found out a significant difference between male and female students in their use of A-E and E-A dictionaries. Alhaisoni (ibid) also claims that students prefer to use mobile dictionaries to look up the meaning of unknown words (mean $=3.47$; SD $=1.334)$. This study also demonstrates that female students use mobile phone dictionaries and google translator more than male students. This study also highlights the point that "high proficiency level students use mobile phone dictionaries and google translator more than low proficiency level students". So far as the teachers' perception regarding the use of dictionaries is concerned, the researcher maintains that teachers are fully convinced of the usefulness of the introduction of mobile phone dictionaries in language classroom.

Tananuraksakul (2015) has conducted a study to investigate the effect of the use of online dictionaries on the EFL learners' autonomy in their writing skills. EFL learners' proficiency can be promoted by fostering their autonomy which can be done in a formal setting as writing is such a skill that needs practice over a period of time (Nhan \& Lai, 2012; Dafei, 2007). Tananureksakul (ibid) maintains that he had aimed to help Thai EFL learners to develop autonomy in writing tasks because he had found talking dictionaries did not help them much as these EFL learners could not learn how to write a paragraph and these EFL learners also committed errors in their sentence structures particularly with reference to verb patterns. So, the researcher has conducted this study to explore how the use of online dictionaries and indirect feedback from teachers can enhance their autonomy in writing tasks. In higher education, autonomy is considered of paramount importance (Arnold, 2006) as it ensures lifelong learning (Little, 2001). Autonomy means capacity (Dam et al., 1990) to behave like a responsible person, an attitude (Dickinson, 1995) which makes a person take ownership and control of his learning (Benson, 2001). EFL teachers can play an important role in developing students' autonomy in their writing skill by giving explicit feedback and positive reinforcement (Srichanyachon, 2012). Tananuraksakul (ibid) selected and used Cambridge Dictionary Online as a resource because the researcher believes that students can develop their learning strategies better when they find learning technology related to their daily life. Thus, they feel motivated to learn English language through a link on their smart phones. The researcher has used this online dictionary as a resource to educate the subjects of this study how to use online dictionary in their writing assignments. For instance, they were asked to find the use of main verb in a sentence and different verb patterns in sentences as models for their writing practices. After the completion of this practice phase, the researcher administered a questionnaire to the subjects of this study to seek their views regarding effectiveness of the use of online dictionaries in an EFL classroom. The results of this study show that the subjects of this study have found the use of online dictionaries very useful to foster their autonomy in their English language. This study has also highlighted the point that EFL leaners' autonomy is closely related with their motivation in learning English language.

\section{Methodology}

This study strives to find answers to the questions what EFL teachers' perception is regarding the use of mobile phone dictionaries in university students' English class and what the challenges are in the introduction of mobile phone dictionaries in university students' English class. This study is primarily quantitative in nature. So, the researcher has gone for the 
quantitative research methodology. According to Dornyei (2011), "quantitative research involves data collection procedures that result primarily in numerical data which is then analyzed primarily by statistical methods." Typical example: survey research using a questionnaire, analyzed by statistical software such as SPSS.

\subsection{Participants of the Study}

The subjects of the present study are 50 (male and female) English language teachers who are working at different Government Colleges of Pakistan.

\subsection{Research Instrument}

The researcher has developed a questionnaire to achieve the set objectives of the study. This questionnaire consists of two sections. The first section comprises fifteen close-ended items on Likert scale from "strongly agree" to "strongly disagree". The second section comprised of two open-ended questions focusing on seeking the participants' opinions regarding the challenges in the introduction of mobile phone dictionaries in the university EFL learners' classrooms and how the use of mobile phone dictionary in class can be made more useful. The close-ended questionnaire items for the first section were pooled by reviewing different studies in the field and going through their findings. After this, the researcher requested two experts to analyze the questionnaire critically and render their expert opinion regarding the validity of this instrument. Before going for the piloting of the instrument, the researcher incorporated the changes recommended by the experts.

The Alpha reliability of this questionnaire is calculated as .721.

\section{Results and Findings}

Table 1. Respondents' response regarding the introduction of mobile phone dictionary in university EFL learners' class

\begin{tabular}{|c|c|c|c|c|c|c|c|c|}
\hline S. No. & Q. Item & SA & A & NO & $\mathbf{D}$ & SD & Mean & SD \\
\hline 1 & Mobile dictionary is easier to access. & 36 & 14 & 0 & 0 & 0 & 4.72 & .454 \\
\hline 2 & $\begin{array}{l}\text { Mobile dictionary can be a useful tool } \\
\text { for EFL university students. }\end{array}$ & 45 & 5 & 0 & 0 & 0 & 4.9 & .303 \\
\hline 3 & $\begin{array}{l}\text { Students should be allowed to use } \\
\text { mobile dictionary in EFL reading } \\
\text { class. }\end{array}$ & 45 & 1 & 4 & 0 & 0 & 4.82 & .56 \\
\hline 4 & $\begin{array}{l}\text { Mobile phone dictionaries are } \\
\text { user-friendly. }\end{array}$ & 45 & 5 & 0 & 0 & 0 & 4.9 & .303 \\
\hline 5 & $\begin{array}{l}\text { The role of teacher is changing with } \\
\text { the explosion of information. }\end{array}$ & 31 & 19 & 0 & 0 & 0 & 4.62 & .49 \\
\hline 6 & $\begin{array}{l}\text { The use of mobile phone dictionary in } \\
\text { an EFL Classroom can be a step } \\
\text { towards smart classrooms. }\end{array}$ & 19 & 31 & 0 & 0 & 0 & 2.76 & .981 \\
\hline 7 & $\begin{array}{l}\text { The use of mobile phone dictionary } \\
\text { can help students become independent } \\
\text { learners. }\end{array}$ & 18 & 30 & 2 & & & 2.75 & .979 \\
\hline
\end{tabular}


\begin{tabular}{lllllllll}
\hline 8 & Students can become life-long learners & 46 & 4 & 0 & 0 & 0 & 3.84 & .548
\end{tabular} by using mobile phone dictionary.

It can also extend their learning out of classroom anywhere anytime.

EFL learners can amplify personal and academic interest with the help of mobile learning.

Mobile dictionary can offer students access to authentic content.

Mobile dictionary can help the university EFL learners to develop their reading comprehension.

Mobile phone dictionary can increase students' language learning motivation.

Peer-assisted language learning can be promoted through using mobile phone dictionary.

5

The use of technology in foreign language class helps EFL learners lower their anxiety.

Table 1 shows that almost all the participants opine that mobile phone dictionary is easier to access, a useful tool and can help the Pakistani university EFL learners extend their learning and be life-long learners. They are also of the view that the use of mobile phone dictionary will help the EFL learners to access authentic material and content which will in return develop their reading comprehension. Of the participants, $94 \%$ believe that the use of mobile phone dictionary in an EFL class will help them lower their anxiety while $86 \%$ maintain that mobile phone dictionary can amplify their motivation.

\section{Discussion}

The findings of this study reveal that Pakistani EFL learners can get a chance to extend their learning which will help them to improve their language. The findings of the study conducted by Rahimi and Miri (2014) second the findings of the present study that mobile dictionaries help EFL learners achieve higher level of language learning. The findings of the previous studies also corroborate the findings of this study that the use of technology in an EFL classroom can exercise a positive effect on students' achievement in language leaning. This study has also found out that the use of mobile phone dictionary can enhance the Pakistani EFL learners' motivation. Likewise, the study conducted by Rahimi and Hosseini (2011) has also reached the findings that EFL learners' motivation can be promoted and a positive attitude towards language learning can be developed in them through introducing and using 
technology in an English classroom.

According to the findings of this study, the use of mobile phone dictionary in university EFL learners' class will help them lower their anxiety in language class. The findings of the study conducted by Rahimi and Yadollahi (2011) also second this view that technology-oriented instruction helps EFL learners to lower their anxiety in language class. According to experts EFL learners are willing and keen to use electronic dictionaries as different studies have found that majority of the EFL leaners own electronic dictionaries and use them in EFL classroom (Kobayashi, 2008; Bower \& McMillan, 2007; Perry, 2003; Tang, 1997; Deng, 2005; Stirling, 2005; Boommoh \& Nesi, 2008). While discussing the positive payoffs of the use of mobile phone dictionary in an EFL classroom, Alhaisoni's (2016) study reveals that majority of the Saudi Arabian EFL learners preferably use mobile phone dictionaries to find the meanings of unknown words. The results of this study also show that students who have high level of proficiency use mobile phone dictionaries more than the students who have low proficiency level. The researcher also maintains that female students use mobile dictionaries and google translator more than male students.

The findings of the present study also demonstrate that university students can become independent and life-long learners through the introduction and use of mobile phone dictionary in class. These findings have also been seconded by the study conducted by Tananuraksakul (2015) who argues that the use of online dictionary in an EFL classroom fosters leaners' autonomy in their writing skills as they learn about variety of verb patterns in different sentence structures through the use of this resource. Moreover, this study also seconds the findings of the present study that the use of such digital tools raises EFL learners' motivation and ensures their high level of proficiency. In the same way, the findings of the study conducted by Mohammad et al. (2017) also second the findings of the present study. According to Mohammad et al. (ibid), EFL teachers and students opine that e-dictionaries are quite useful in the process of language learning just because of those features of e-dictionaries which render them user-friendly. Lew (2010) also states that more "interactive ways of finding the meanings of words" are offered by e-dictionaries than the printed ones. Lou and Li (2012) claim that e-dictionaries are used more preferably by the matured language learners. Likewise, Amirian and Heshmatifer (2013) maintain that e-dictionaries is indeed such a tool that helps EFL learners to develop their vocabulary, boost their motivation and foster their interactive learning. Fageeh (2014) also argues that EFL learners can recognize and identify the origin and meanings of a word with the help of an e-dictionary quite easily.

This study has also aimed to highlight the problems in introducing mobile phone dictionary in university students' English class. Accordingly, some issues have been brought to light in the present study. The participants maintain that the problem of the diversion of students' attention is one of the issues which can pose challenge in introducing mobile phone dictionary in university students' class. They opine that students' attention can be diverted from the topic being taught in the class because of the use of mobile phone. Apart from this, the problem of synchronization has also been pointed out by the respondents of this study. Some of the participants have also claimed that the introduction of mobile phone dictionary in university EFL learners' class may give rise to the problem of controlling the class and making them focused especially in the large classes. The findings of the study conducted by 
Ayoub et al. (2017) also highlight the point that the lack of training and guidance from teachers cause problems for the Pakistani EFL learners in using dictionary properly. This study has also thrown light on the fact that majority $(80 \%)$ of the participants do not use dictionary in their classroom. Regarding the habits of the Pakistani EFL learners' dictionary use, this study has found out that mostly these learners use dictionary only to know the meanings of words.

\section{Conclusion}

This study aimed to get insight into teachers' perspective regarding the introduction of mobile phone dictionary in university EFL learners' class and explore the challenges which can be faced to this end. So far as the first objective is concerned, this study has found out that an overwhelming majority of the participants believes that the introduction and use of mobile phone dictionary in an EFL classroom can render very useful and multifaceted pay offs. On the other hand, this study has also brought to light such problems that can prove an impediment in the introduction of mobile phone dictionary in university EFL learners' class in Pakistani context. These problems include the diversion of the students' attention and focus, the issue of synchronization and time management. But these problems can be surmounted by enhancing class time, providing some technical aids, giving strict instructions and striking synchronization in the class. There is no denying the fact that EFL learners can develop their language competence through the use of mobile phone dictionary in their foreign language classroom setting.

\section{References}

Amirian, S. M. R., \& Heshmtifar, Z. (2013). The Impact of Using Electronic Dictionary on Vocabulary Learning and Retention of Iranian EFL Learners. International Journal of Research Studies in Educational Technology, 2(1), 35-44. https://doi.org/10.5861/ijrset. 2013.384

Alhaisoni, E. (2016). EFL Teachers' and Students' Perceptions of Dictionary Use and Preferences. International Journal of Linguistics, 8(6), 31-52. https://doi.org/10.5296/ijl.v8i6. 10267

Arnold, L. (2006). Understanding and Promoting Autonomy in UK Online Higher Education. International Journal of Instructional Technology and Distance Learning, Vol. 3, No. 7,

Ayoub, M. T., Mehmood, K., \& Awan, A. G. (2017). A Study of Dictionary Using Habits of Students at Secondary Level in the Urdu Medium Schools in District Khanewal - Pakistan. Global Journal of Management, Social Sciences and Humanities, 3(3), 515-533.

Benson, P. (2001). Teaching and Researching Autonomy in Language Learning. Harlow: Longman.

Boonmoh, A., \& Nesi, H. (2008). A Survey of Dictionary Use by Thai University Staff and Students, with Special Reference to Pocket Electronic Dictionaries. Horizontes de Lingustica Aplicada, 6(2), 79-90.

Bower, J., \& Brain, M. (2007). Learner's Use and Views of Portable Electronic Dictionaries. In K. Bradford-Watts (Ed.), JALT 2006 Conference Proceedings (pp. 697-708). Tokyo: JALT. Castells, M. (2000). The Rise of Network Society. The Information Age: Economy, Society and Culture, Cambridge, MA; Oxford: Blackwell. 


\section{Macrothink}

Education and Linguistics Research ISSN 2377-1356 2019, Vol. 5, No. 2

Dafei, D. (2007). An Exploration of the Relationship between Learner Autonomy and English Proficiency. Asian EFL Journal.

Dam, L., Erikson, R., Little, D., Miliander, J., \& Trebbi, T. (1990). Towards a Definition of Autonomy. In T. Trebbi (Ed.), Third Nordic Workshop on Developing Autonomous Learning in the EL Classroom (pp. 102-103). Bergen: University of Bergen.

Dashtestani, R. (2013). EFL Teachers' and Students' Perspectives on the Use of Electronic Dictionaries for Learning English. Call-Ej, 14(2), 51-65. https://doi.org/10.1016/0346251X(95) 00005-5

Deng, Y. P. (2005). A Survey of College Students' Skills and Strategies of Dictionary Use in English Learning. CELEA Journal, 28(4), 73-77.

Dickinson, L. (1995). Autonomy and Motivation: A Literature Review. System, 23(2), 165-174.

Dornyei, Z. (2011). Research Methods in Applied Linguistics: Qualitative, Quantitative and Mixed Methodologies. Oxford University Press

Fageeh, A. I. (2014). Effects of Using the Online Dictionaries for Etymological Analysis on Vocabulary Development in EFL College Students. Theory and Practice in Language Studies, 4(5), 883-890. https://doi.org/10.4304/tpls.4.5.883-890

Ghani, M. (2003). The Status and Position of English Language in Pakistan. Journal of Social Sciences and Humanities, 1(1).

Inami, K., Nishikata, A., Nakayama, M., \& Shimuzu, Y., (1997). Effectiveness of learning English words using a CD-ROM dictionary. Japan Journal of Educational Technology, 21(2), 107-117. https://doi.org/10.1108/eb024615

Joseph, S., \& Uther, M. (2009). Mobile Devices for Language Learning: Multimedia Approach. Research and Practice in Teaching Enhanced Learning, 4, 7-32. https://doi.org/10.1142/S179320680900060X

Klopfer, E., \& Squire, K. (2008). Environmental Detectives the Development of an Augmented Reality Platform for Environmental Simulation. Educational Technology Research \& Development, 56, 203-228. https://doi.org/10.1007/s11423-007-9037-6

Kobayashi, C. (2008). The Use of Pocket Electronic and Printed Dictionaries: A Mixed-method Study. In K. B. Watts, T. Muller, \& M. Swanson (Eds.), JALT 2007, Conference Proceedings (pp. 769-783). Tokyo: JALT

Korat, O., \& Shamir, A. (2006). The Educational Electronic Book as a Tool for Supporting Children's Emergent Literacy in Low Versus Middle SES Groups. Computers and Education, 50, 110-124. https://doi.org/10.1016/j.compedu.2006.04.002

Lankshear, C., \& Knobel, M. (2003). New Literacies: Changing Knowledge and Classroom Learning. Buckingham \& Philadelphia: Open University Press.

Lew, R. (2010). Multimodal Lexicography: The Representation of Meaning in Electronic Dictionaries. Lexikos Journal, 290-360. https://doi.org/10.4314/lex.v20i1.62717

Little, D. (2001). Learner Autonomy and the Challenge of Tandem Language Learning Via the Internet. In A. Chambers \& G. Davis (Eds.), ICT and Language Learning: A European Perspective (pp. 29-38). Amsterdam: Swets \& Zeitlinger Publishers. 
Midlane, V. (2000). Students' Use of Portable Electronic Dictionaries in EFL/ESL Classroom: A Survey of Teacher Attitude. Manchester: University of Manchester, Faculty of Education.

Nesi, H. (1999). A User's Guide to Electronic Dictionaries for Language Learner. International Journal of Lexicography, 12(1), 55-66. https://doi.org/10.1093/ij1/12.1.55

Nhuyen, T. N., \& Lai, T. (2012). The Enhancement of Learner Autonomy and the Growth of English Language Proficiency. Language in India, 12, 427-439.

Perry, B. (2003). The Use of Pocket Electronic Dictionaries (PEDs) by Japanese University Students. The Review of Liberal Arts, 105, 165-176.

Rahimi, M., \& Hosseini, F. (2011). The Impact of Computer-based Activities on Iranian High-School Student' Attitudes towards Computer-Assisted Language Learning. Procedia Computer Science, 3, 183-190. https://doi.org/10.1016/j.procs.2010.12.031

Rahimi, M., \& Miri, S. S. (2014). The Impact of Mobile Dictionary Use on Language; Learning. Procedia - Social and Behavioral Sciences: International Conference on Current Trends in ELT, 98, 1469-1474. https://doi.org/10.1016/j.sbspro.2014.03.567

Rahimi, M., \& Yadollahi, S. (2011). Success in Learning English as a Foreign Language as a Predictor of Computer Anxiety. Procedia Computer Science, 3, 175-182. https://doi.org/10. 1016/j.procs.2010.12.030

Srichanyachon, N. (2012). Teacher Written Feedback for L2 Learners' Writing Development. Silpakron University Journal of Social Sciences, Humanities and Arts, 12(1), 7-17.

Stirling, J. (2005). The Portable Electronic Dictionaries Faithful Friend or Faceless Foe? Modern English Teacher, 14(3), 64-72.

Tananuraksakul, N. (2014). Use of Facebook Group as Blended Learning and Learning Management System Writing. Teaching English with Technology, 14(3), 3-15.

Tananuraksakul, N. (2015). The Effect of Online Dictionaries Usage on EFL Undergraduate Students' Autonomy. Teaching English with Technology, 15(4), 3-15.

Tang, G. (1997). Pocket Electronic Dictionaries for Second Language Learning: Help or Hindrance? TESL Canada Journal, 15(1), 39-57. https://doi.org/10.18806/tesl.v15i1.691

Warschauer, M. (1999). Electronic Literacies: Language, Culture, and Power in Online Education. Mahwah, NJ: Lawrence Erlbaum Associates. https://doi.org/10.4324/978141 0604682

Zheng, H. \& Wang, X. (2016). The Use of Electronic Dictionaries in EFL Classroom. Studies in English Language Teaching, 4(1), 144-156. https://doi.org/10.22158/selt.v4n1p144

\section{Copyright Disclaimer}

Copyright reserved by the author(s).

This article is an open-access article distributed under the terms and conditions of the Creative Commons Attribution license (http://creativecommons.org/licenses/by/3.0/). 